\title{
Development of innovative methods for risk assessment in high-rise construction based on clustering of risk factors
}

\author{
Ella Okolelova ${ }^{1,{ }^{*}}$ Marina Shibaeva ${ }^{1}$, Oleg Shalnev ${ }^{1}$ \\ ${ }^{1}$ Voronezh State Technical University, Moscow Avenue, 14, Voronezh, 394026, Russia
}

\begin{abstract}
The article analyses risks in high-rise construction in terms of investment value with account of the maximum probable loss in case of risk event. The authors scrutinized the risks of high-rise construction in regions with various geographic, climatic and socio-economic conditions that may influence the project environment. Risk classification is presented in general terms, that includes aggregated characteristics of risks being common for many regions. Cluster analysis tools, that allow considering generalized groups of risk depending on their qualitative and quantitative features, were used in order to model the influence of the risk factors on the implementation of investment project. For convenience of further calculations, each type of risk is assigned a separate code with the number of the cluster and the subtype of risk. This approach and the coding of risk factors makes it possible to build a risk matrix, which greatly facilitates the task of determining the degree of impact of risks. The authors clarified and expanded the concept of the price risk, which is defined as the expected value of the event, 105 which extends the capabilities of the model, allows estimating an interval of the probability of occurrence and also using other probabilistic methods of calculation.
\end{abstract}

\section{Introduction}

The development of high-rise construction as a global process of urbanization is happening at a high pace in many countries. The shortage of land resources, the aspiration to change the cityscape, make it more modern and attractive not only for residents but also for tourists, and also the objective to increase the area of construction for trade, office and residential facilities make architects strive to search for new constructional forms and engineering solutions.

Many countries actively develop high-rise construction as a new branch of the construction industry with a view to the most rational use of land resources. At the same time with the erection of buildings that impressively rise above the ground, investors do not forget about its depths and build, if not underground cities, a very significant underground structure. All this allows initiators of high-rise construction projects to carry out the principle of obtaining maximum profit from a limited building area.

\footnotetext{
* Corresponding author: Ella.o2011@yandex.ru
} 
Undoubtedly, from the point of view of builders and architects, the decoration of cities with modern buildings is not only a tribute to urban fashion, the beauty of the cityscape and its more modern look, but also convenience, new residential and commercial spaces, new jobs, a new lifestyle.

From an investor's point of view, any project is a risk. High-rise construction is a special category of facilities, which carries an even higher level of risks. Much depends on the geographical features of the construction region, the level of social development, the mentality of the population and many other factors, that are identified as project risks.

In countries, which experience a lack of construction sites, high-rise construction is a prerequisite not only for the dynamic development of the construction industry, but also for ensuring the necessary standard of living and the activities of society as a whole. At the same time, each country has its own peculiarities, which determine the risk values and the probability of losses for the investor within the implementation of the high-rise construction project. The cost of construction depends largely on the types and levels of country and project risks.

For instance, the important factors, that determine the cost of construction of high-rise buildings, are the climatic conditions. Ground movements, the influence of the waters, wind load complicate the project and cause a significant rise in price not only at the design stage of the object, but also during construction. The geography of the country largely determines the level of risks and potential natural and climatic threats. Nevertheless, risks associated with the socio-political and economic level of development should be taken into account.

Thus, speaking of various kinds of risks from the point of view of investment costs, it is necessary to understand that reducing the impact of risks is, first of all, a rise in the construction cost. For example, it is required to apply new technologies and modern methods, when building a life support system for a high-rise facility, as well as specialists who have the necessary skill level to install and subsequently operate it. All this causes a significant rise in the construction cost of facilities, despite of construction of high-rise buildings in climatically dangerous regions, including seismically active and coast zones, mountainous areas, etc. High-rise buildings constructed in such zones require to use structures of a different type in order to preserve the resistibility of buildings during the adverse impact of natural and climatic factors.

Therefore, the problem of risks can be considered as a price factor that affects the investment cost of constructiont o a certain extent. The most likely and common types of risks are considered in order to quantitatively evaluate the risks as a practical tool for assessing the level of danger for a high-rise facility.

A lot of works of domestic and foreign scientists, such as Maklakova T.G., Almazov V.O., Granik Y.G., Burkov V.N., Trukhina N.I., Pham H. X., are focused on the problem of risk evaluation. These works provide a risk evaluation, including analysis of the construction industry in terms of various options for implementing investment projects. The issues of classification, analysis and assessment of risks of high-rise construction require separate consideration due to their specifics, what has determined the relevance of the work.

The goal of the study is to develop a risk analysis model that allows determining the investment value of risk taking into account the probability of a risk event and possible consequences.

\section{Materials and Methods}

Statistical data of observations, statistical analysis, which allows to evaluate systemic and non-systemic risks of high-rise construction in different regions, are applied in the work as an empirical method of research. The method of mathematical modeling, dwelled on cluster 
analysis, allows assessing the degree of impact of risks and the possible consequences in case of risk events [1].

Risks are differentiated by characteristics and are united into clusters by these characteristics. For convenience of further calculations, each type of risk is assigned a separate code with the number of the cluster and the subtype of the risk.

Table 1. Risk classification in high-rise construction

\begin{tabular}{|c|c|c|}
\hline \multicolumn{2}{|r|}{ Types of risks in terms of impact and consequences } & Code \\
\hline Impact & Possible consequences & \\
\hline \multicolumn{3}{|c|}{ Cluster 1 (Geological, geographical and climatic risks) } \\
\hline Seismic activity & $\begin{array}{l}\text { Destruction of buildings and structures as a result of earthquakes } \\
\text { of various strengths }\end{array}$ & 101 \\
\hline $\begin{array}{l}\text { Impact of waters, } \\
\text { including seas and } \\
\text { oceans }\end{array}$ & Possibility of hurricanes, typhoons, tsunami, floodings, etc. & 102 \\
\hline $\begin{array}{l}\text { Factor of a } \\
\text { mountainous area }\end{array}$ & Possibility of diastrophic activity, avalanches and mudflows & 103 \\
\hline \multicolumn{3}{|c|}{ Cluster 2 (Country risks) } \\
\hline \multicolumn{3}{|c|}{ 1. Political } \\
\hline Legal support & $\begin{array}{l}\text { Absence of the necessary regulatory framework to develop the } \\
\text { high-rise construction (land ownership and real estate issues, } \\
\text { protection of investor interests, financial institutions, credit } \\
\text { facilities, etc.) }\end{array}$ & 211 \\
\hline $\begin{array}{l}\text { Legislative } \\
\text { framework }\end{array}$ & $\begin{array}{l}\text { Absence of the necessary normative acts for the high-rise } \\
\text { construction (issues of land notification, ecology, urban } \\
\text { development planning, construction regulations, etc.) }\end{array}$ & 212 \\
\hline Criminality rate & Threat of terrorist attacks, protests of the population, etc. & 213 \\
\hline \multicolumn{3}{|c|}{ 2. Economic } \\
\hline Inflation rate & $\begin{array}{l}\text { Devaluation of the national currency, drop of the exchange rate, } \\
\text { rise in the cost of materials and resources. }\end{array}$ & 221 \\
\hline $\begin{array}{l}\text { Level of economic } \\
\text { development }\end{array}$ & $\begin{array}{l}\text { Negative consequences of the general economic crisis, possible } \\
\text { economy contraction, a decline in incomes of population, } \\
\text { absense of a developed real estate market, a decrease in } \\
\text { effective demand, insufficient development of construction and } \\
\text { related industries, a lack of material and technical base to } \\
\text { develop high-rise construction, a lack of foreign investment, } \\
\text { access to credit resources, taxation, etc. }\end{array}$ & 222 \\
\hline \multicolumn{3}{|c|}{ 3. Social } \\
\hline Unemployment rate & $\begin{array}{l}\text { Lack of trained specialists to develop high-rise construction in } \\
\text { the region }\end{array}$ & 231 \\
\hline $\begin{array}{l}\text { Social } \\
\text { differentiation }\end{array}$ & $\begin{array}{l}\text { Decline in income per capita, increase in the number of people } \\
\text { living below the living minimum wage, etc.) }\end{array}$ & 232 \\
\hline Local mentality & $\begin{array}{l}\text { The discontent and protests of the population against the active } \\
\text { urbanization of the country. }\end{array}$ & 233 \\
\hline \multicolumn{3}{|c|}{ Cluster 3 (Investment risks) } \\
\hline Supply of capital & $\begin{array}{l}\text { Lack of the necessary amount of equity capital, the difficulty of } \\
\text { attracting foreign investors, insufficiently developed credit } \\
\text { mechanisms, high loan interest rates, etc. }\end{array}$ & 301 \\
\hline $\begin{array}{l}\text { Growth of } \\
\text { investment } \\
\text { expenditures }\end{array}$ & $\begin{array}{l}\text { Land notification; administrative and legal decisions; rise in } \\
\text { price of materials; the complexity of object construction and the } \\
\text { use of high-strength structures; expenses for innovation (new } \\
\text { materials, technologies, methods of production and } \\
\text { management); utility systems; object maintenance; green issues, } \\
\text { etc. }\end{array}$ & 302 \\
\hline Market risks & The difficulty to enter new markets for construction products, & 303 \\
\hline
\end{tabular}




\begin{tabular}{|c|c|c|}
\hline \multicolumn{2}{|r|}{ Types of risks in terms of impact and consequences } & Code \\
\hline & $\begin{array}{l}\text { reducing the effective demand of consumers, the dynamics of } \\
\text { the value of real estate, etc. }\end{array}$ & \\
\hline Inflation risks & $\begin{array}{l}\text { The duration of the construction of the facility, long terms of } \\
\text { positioning, the complexity to anticipate profit, etc. }\end{array}$ & 304 \\
\hline \multicolumn{3}{|c|}{ Cluster 4 (Technological risks) } \\
\hline Project risks & $\begin{array}{l}\text { Design failures of a high-rise building (geological surveys, } \\
\text { account of natural and climatic conditions, design features, etc.) }\end{array}$ & 401 \\
\hline $\begin{array}{l}\text { Complexity of } \\
\text { erection }\end{array}$ & $\begin{array}{l}\text { Insufficient provision of machinery, mechanisms and structural } \\
\text { components necessary for high-rise construction }\end{array}$ & 402 \\
\hline $\begin{array}{l}\text { Complexity of } \\
\text { service }\end{array}$ & $\begin{array}{l}\text { Lack of profile services to ensure constant and trouble-free } \\
\text { operation of utility systems, lack of a control system for high- } \\
\text { rise facilities }\end{array}$ & 403 \\
\hline \multicolumn{3}{|c|}{ Cluster 5 (Operational risks) } \\
\hline $\begin{array}{l}\text { Failures of life } \\
\text { support systems }\end{array}$ & $\begin{array}{l}\text { Time eliminate the emergency and restore the operation of the } \\
\text { systems; impossibility to restore the working capacity of } \\
\text { technical systems during the normalized recovery time }\end{array}$ & 501 \\
\hline Fire risks & $\begin{array}{l}\text { Absence or malfunction of the fire safety system, the difficulty } \\
\text { of evacuating people in emergency cases; local destruction of } \\
\text { structural elements of buildings, etc. }\end{array}$ & 502 \\
\hline Explosion risks & $\begin{array}{l}\text { Detection of chemically hazardous substances in the building; } \\
\text { The threat of destruction of the structure of a building partially } \\
\text { or completely due to the presence of explosive chemicals }\end{array}$ & 503 \\
\hline \multicolumn{3}{|c|}{ Cluster 6 (Environmental risks) } \\
\hline Technological risks & $\begin{array}{l}\text { Increased costs for the use of modern technologies to create life } \\
\text { support systems (energy-saving technologies, water use and } \\
\text { treatment systems, sewage filtration system, etc.) }\end{array}$ & 601 \\
\hline Natural risks & $\begin{array}{l}\text { Possibility to offset the use of the country's natural resources } \\
\text { (deforestation, water pollution, landscape modification, } \\
\text { violation of the natural and ecological balance, etc.) }\end{array}$ & 602 \\
\hline
\end{tabular}

Risks are evaluated by the likelihood of occurrence and the degree of impact. The likelihood of risk occurrence is determined on the basis of statistical observations and anticipations on the probability of events. The probability of an event can be evaluated as the frequency of its occurrence in practice or the modeling of the situation. The idea of the suggested method is to assess the likelihood of risk occurrence, as well as to evaluate the frequency and the scale of possible damage from the risk event [2].

Thus, the price risk can be defined as the amount of probable loss in the event of adverse effects. If the probability of occurrence of $i$-th risk is $p_{i}$ and the value of possible losses is $V_{i}$, the price risk is defined by:

$$
R=\sum_{i=1}^{n} p_{i} V_{i}
$$

The price risks are losses with account of the probability of its occurrence. This statement allows us to construct a risk matrix where the loss value is defined as a percentage of the maximum possible damage. The price risk can be determined in terms of value, but in this case it is more correct to use relative values. Thus, the price risk is calculated as a relative indicator and is presented as a percentage of the cost of construction. In accordance with the classification, the probabilities of events and the value of the maximum loss are determined. Identification of risks by qualitative and quantitative characteristics was carried out on the basis of cluster analysis, which makes it possible to group risks not only by sources of their occurrence and likelihood of occurrence, but also by the value of damage [3]. As a method of quantitative risk analysis, it is suggested to allocate risks in terms of significance, which assumes the maximum possible loss when 
implementing an investment project. Table 2 presents the results of assessing the likelihood of occurrence of risks and the value of the maximum loss according to the impact.

Table 2. Quantitative risk analysis

\begin{tabular}{|c|c|c|c|}
\hline Code & $\begin{array}{c}\text { Likelihood of } \\
\text { occurrence }\end{array}$ & $\begin{array}{c}\text { Maximum loss,\% of } \\
\text { the construction cost }\end{array}$ & $\begin{array}{c}\text { Price risk,\% of the } \\
\text { construction cost }\end{array}$ \\
\hline 101 & 0.1 & 90 & 9.00 \\
\hline 102 & 0.1 & 90 & 9.00 \\
\hline 103 & 0.1 & 80 & 8.00 \\
\hline 211 & 0.15 & 10 & 1.50 \\
\hline 212 & 0.15 & 10 & 1.50 \\
\hline 213 & 0.2 & 10 & 2.00 \\
\hline 221 & 0.5 & 20 & 10.00 \\
\hline 222 & 0.4 & 30 & 12.00 \\
\hline 231 & 0.2 & 15 & 3.00 \\
\hline 232 & 0.2 & 10 & 2.00 \\
\hline 233 & 0.1 & 5 & 0.50 \\
\hline 301 & 0.5 & 20 & 10.00 \\
\hline 302 & 0.3 & 25 & 7.50 \\
\hline 303 & 0.6 & 15 & 9.00 \\
\hline 304 & 0.8 & 20 & 16.00 \\
\hline 401 & 0.7 & 25 & 17.50 \\
\hline 402 & 0.5 & 25 & 12.50 \\
\hline 403 & 0.3 & 20 & 6.00 \\
\hline 501 & 0.3 & 60 & 18.00 \\
\hline 502 & 0.3 & 60 & 18.00 \\
\hline 503 & 0.3 & 50 & 22.50 \\
\hline 601 & 0.75 & 30 & 4.00 \\
\hline 602 & 0.4 & 10 & 15.00 \\
\hline 1395 & & 0 & \\
\hline
\end{tabular}

Based on the exact price risk, a cluster grouping was conducted. The complexity of the problem is in the fact that certain types of risk according to the conditions of empirical observations have a very low probability to occur. These risks, for example, may include man-made disasters. At the same time, the damage will be very great in case of their event. And vice versa: risks, that have a high probability to occur, do minor damage to investment project. The objective of risk analysis is to detect the most active group of risks with relatively high likelihood of occurence and value of damage.

Grouping of objects by a number of characteristics is performed on the basis of methods of cluster analysis. The parameter of clustering is the price risk. The range of price risk is $[0.5 ; 22.5]$. Clusters are formed on the basis of the price risk in the order of increasing of the specified parameter (Table 3 ).

Table 3. Clustering by price risk.

\begin{tabular}{|c|c|c|c|}
\hline Code & $\begin{array}{c}\text { Likelihood of } \\
\text { occurrence }\end{array}$ & $\begin{array}{c}\text { Maximum loss,\% of the } \\
\text { construction cost }\end{array}$ & $\begin{array}{c}\text { Price risk,\% of the } \\
\text { construction cost }\end{array}$ \\
\hline 233 & 0.1 & 5 & 0.5 \\
\hline 211 & 0.15 & 10 & 1.5 \\
\hline 212 & 0.15 & 10 & 1.5 \\
\hline 213 & 0.2 & 10 & 2 \\
\hline 232 & 0.2 & 10 & 2 \\
\hline 231 & 0.2 & 15 & 3 \\
\hline
\end{tabular}




\begin{tabular}{|c|c|c|c|}
602 & 0.4 & 10 & 4 \\
\hline 403 & 0.3 & 20 & 6 \\
\hline 302 & 0.3 & 25 & 7.5 \\
\hline 103 & 0.1 & 80 & 8 \\
\hline 101 & 0.1 & 90 & 9 \\
\hline 102 & 0.1 & 90 & 9 \\
\hline 303 & 0.6 & 15 & 9 \\
\hline 221 & 0.5 & 20 & 10 \\
\hline 301 & 0.5 & 20 & 10 \\
\hline 222 & 0.4 & 30 & 12 \\
\hline 402 & 0.5 & 25 & 12.5 \\
\hline 503 & 0.3 & 50 & 15 \\
\hline 304 & 0.8 & 20 & 16 \\
\hline 401 & 0.7 & 25 & 17.5 \\
\hline 501 & 0.3 & 60 & 18 \\
\hline 502 & 0.3 & 60 & 18 \\
\hline 601 & 0.75 & 30 & 22.5 \\
\hline
\end{tabular}

Three main clusters of risks were formed and a cluster classification was introduced based on the qualitative and quantitative analysis (Table 4).

Table 4. Risk clusters

\begin{tabular}{|l|l|c|}
\hline \multicolumn{1}{|c|}{ Risk cluster } & \multicolumn{1}{|c|}{ Description } & Range of price risk \\
\hline $\begin{array}{l}\text { Conservative } \\
\text { risks }\end{array}$ & $\begin{array}{l}\text { Risks that have a low probability of occurrence } \\
\text { and a minor value of damage in case of event }\end{array}$ & {$[0.5 ; 7.5]$} \\
\hline Moderate risks & $\begin{array}{l}\text { Risks that have either an average probability of } \\
\text { occurrence or an average value of damage in } \\
\text { case of event }\end{array}$ & {$[8 ; 15]$} \\
\hline Aggressive risks & $\begin{array}{l}\text { Risks that have either a high probability of } \\
\text { occurrence and a minor value of damage or a } \\
\text { low probability of occurrence, but a significant } \\
\text { value of damage }\end{array}$ & {$[16 ; 22.5]$} \\
\hline
\end{tabular}

The following presents a risk matrix, which displays the risk clusters that pose the greatest threat to the project (Fig. 1).

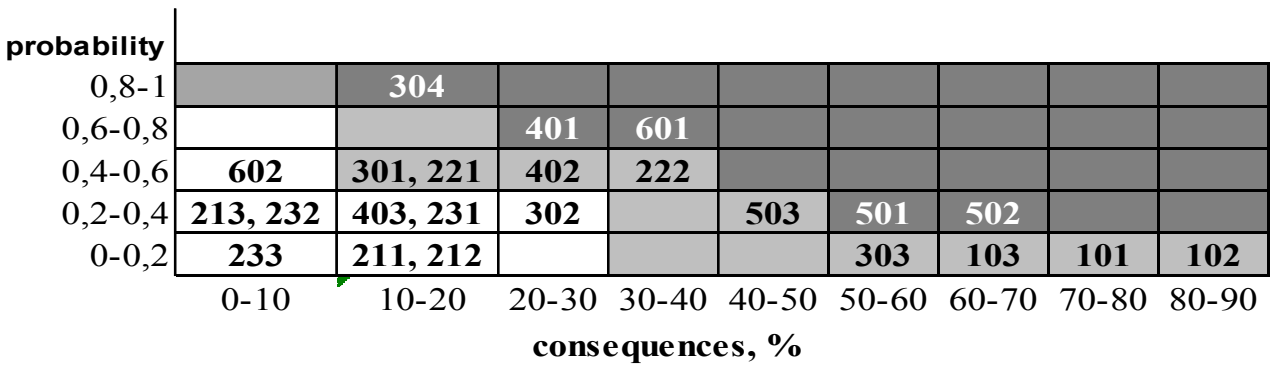

Fig. 1. Risk matrix

Note: the risk clusters are highlighted in Figure 1 with the following colors:

(1) - $\square$ - conservative risks

(2) $-\square$ - moderate risks

(3) - $\square$ - aggressive risks 
All kinds of possible risks are clustered according to certain characteristics. The objective is to determine the impact of each risk cluster on the construction of high-rise buildings.

Therefore, it is necessary to determine the extent of the impact of risks, i.e. it is required to estimate the value of losses in case of unfavorable events for the project. It can be man-made disasters, harsh climate conditions, inflation, political protests in the society and many other factors that can ultimately affect the profitability of the project [4].

As it is shown in Figure 1, three risk clusters have been formed. Each cluster includes risks identical to the price risk, regardless of the nature of the event, the likelihood of occurrence, etc. The range of the price risk was adopted as a basis to form the cluster, which made it possible to identify and group risk factors.

The statement that the factor weight of a group can be represented as a cluster distance between points in a multidimensional factor space was adopted as the working hypothesis of risk analysis. Consequently, the factor influence of each group is calculated as the Euclidean distance:

$$
d_{i j}=\sqrt{\sum_{t=1}^{n}\left(x_{i t}-x_{j t}\right)^{2}}, \quad I, j=1, \ldots, n .
$$

where $d_{i j}$ is the Euclidean distance between the $i$-th and $j$-th objects; $x_{i t}$, is the value of the $i$-th parameter for the $i$-th object.

A square matrix of distances $D$ is obtained with a dimension $n \times n$ (by the number of objects); This matrix is symmetric, i.e. $d_{i j}=d_{i j}(i, j=1, \ldots, n)$.

$$
D=\left(\begin{array}{cccc}
d_{11} & d_{12} & \cdots & d_{1 n} \\
d_{21} & d_{22} & \ldots & d_{2 n} \\
\cdots & \cdots & \cdots & \cdots \\
d_{n 1} & d_{n 2} & \cdots & d_{n n}
\end{array}\right)
$$

As a result, a cluster of risks has been formed that most actively affect the anticipation of the project profitability [5]

\section{Results}

The price risk is defined as the expected value of the event on the basis of the risk study, cluster analysis of risk factors and the determination of mechanisms for calculating the impact of risks on the design and construction of a high-rise facility. This evaluation option is the most accurate. Thus, the considered model allows estimating the interval probability. In this case, all other parameters will also have a certain range of values. Therefore, the developed risk evaluation model allows using various calculation methods.

A further calculation method is presented in the example studied earlier. The distance between clusters is determined in accordance with formula (2), and a distance matrix is constructed (Table 5).

Table 5. Matrix of cluster distances

\begin{tabular}{|c|c|c|c|}
\hline Cluster name & Conservative & Moderate & Aggressive \\
\hline Conservative (1) & 0 & 23.2 & 34.5 \\
\hline Moderate (2) & 23.2 & 0 & 24.6 \\
\hline Aggressive (3) & 34.5 & 24.6 & 0 \\
\hline
\end{tabular}

A "risk triangle" is obtained, which is graphically presented in Figure 2. 


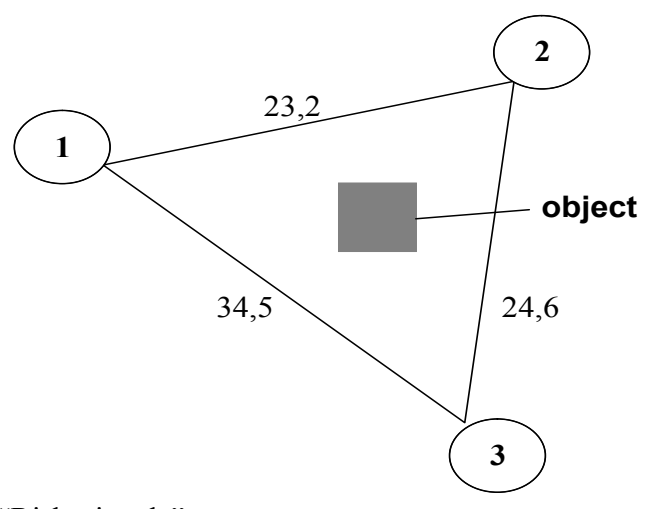

Fig.2. Geometric model "Risk triangle".

Geometric interpretation: The object is in the center of the triangle, i.e. it is at the point of intersection of the medians of the triangle. The degree of impact of each risk cluster (vertixes of the triangle) is determined geometrically as $2 / 3$ of the median [ 6].

Risk clusters are formed on the basis of the price risks, what is the value of expected losses in case of the risk event with account of the probability and maximum damage. The distance between clusters, respectively, is also expressed in terms of the price risk.

If the distance between the vertixes of the triangle increases, so the price risk will grow. It is necessary to determine the lengths of the medians of the triangle in order to determine the degree of influence of the risk clusters on the object (Figure 3).

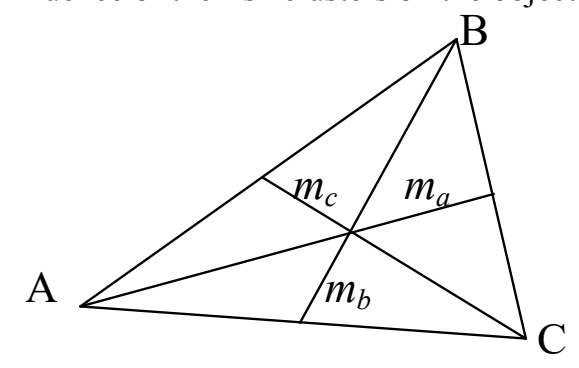

Fig. 3. Geometric interpretation of risks.

The median lengths of the triangle are calculated as follows:

$$
m_{a}=\frac{1}{2} \sqrt{2 b^{2}+2 c^{2}-a^{2}} ; \quad m_{b}=\frac{1}{2} \sqrt{2 a^{2}+2 c^{2}-b^{2}} ; \quad m_{c}=\frac{1}{2} \sqrt{2 a^{2}+2 b^{2}-c^{2}}
$$

Distances for the risk cluster:

$$
\begin{aligned}
& m_{1}=\frac{1}{2} \sqrt{2 \cdot 34,5^{2}+2 \cdot 23,2^{2}-24,6^{2}}=26,7 \\
& m_{2}=\frac{1}{2} \sqrt{2 \cdot 24,6^{2}+2 \cdot 23,2^{2}-34,5^{2}}=16,6 \\
& m_{3}=\frac{1}{2} \sqrt{2 \cdot 34,5^{2}+2 \cdot 24,6^{2}-23,2^{2}}=27,6
\end{aligned}
$$

The center of the triangle is at the intersection of medians, with medians at this point being related as 2:1. Consequently, the degree of influence of the $\mathrm{R}_{\mathrm{ki}}$ risk cluster on the object can be defined as $2 / 3$ of the median length of the corresponding cluster vertex:

$$
\mathrm{R}_{\mathrm{k} 1}=2 \cdot 26.7 / 3=17.8 ; \quad \mathrm{R}_{\mathrm{k} 2}=2 \cdot 16.6 / 3=11.04 ; \quad \mathrm{R}_{\mathrm{k} 3}=2 \cdot 27.6 / 3=18.4 .
$$




\section{Conclusion}

The price of cluster risks is determined and the degree of their influence on the implemetation of the project is investigated. Despite the fact that clusters represent three groups of risks (conservative, moderate and aggressive), the degrees of influence differ slightly. This is due to the fact that the probability of occurrence of a risk with a high level of damage is usually much lower than the probability of occurrence of conservative risks with minor possible damage. Consequently, there is a "leveling" of the price risk, and as a result, risk clusters have almost equal impact on the facility.

Risk evaluation allows not only to assess the value of possible damage with the highest probability, but also to take measures in order to neutralize risks. For example, buildings and facilities are built using more sturdy structures in seismically active zones, where the probability of earthquakes is high.

Based on the suggested model, risks were identified, clustered in order to highlight the most significant ones, and also their impact on the project environment was evaluated.

\section{References}

1. H.K. Fam, Ekonomika i menedzhment sistem upravleniya, 1(7), 111-118 (2013)

2. E.Yr. Okolelova, H.K. Fam, Ekonomika, 7, 23-27 (2011)

3. V.N. Burkov, H.K. Fam, Moscow, 51-56 (2013)

4. I.V. Ilin, A. Lepekhin, A.I. Levina, O.Yu. Iliashenko, Advances in Intelligent Systems and Computing, 692, 1306-1314 (2018) DOi -10.1007/978-3-319-70987-1_138

5. O.V. Kalinina, M.V. Lopatin, Actual Problems of Economics, 182, 392-405 (2016)

6. V. Kankhva, MATEC Web of Conferences, 106, 08027 doi:10.1051/matecconf/201710608027 